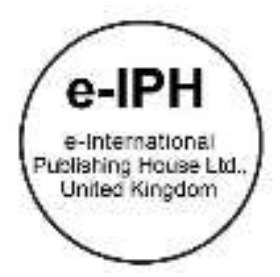

\title{
The Malaysian Garden Concept Design Branding: Whose role is it anyway?
}

\author{
Ahmad Zamil Zakaria ${ }^{1}$, Melasutra Md Dali ${ }^{2}$, Hazreena Hussein ${ }^{2}$ \\ 1 Universiti Teknologi MARA Perak Branch, Seri Iskandar Campus, Perak, Malaysia \\ ${ }^{2}$ Center for Sustainable Urban Planning \& Real Estate, Faculty of Built Environment, University of Malaya, Malaysia \\ zamil227@uitm.edu.my, reenalambina@um.edu.my, melasutr@um.edu.my \\ Tel of 1 st Author: +60122289564
}

\begin{abstract}
Two decades ago, Malaysian leaders had expressed their desire to have a garden design concept that can represent Malaysia. This study explores the Malaysian Garden Concept (MGC) branding from the perspectives of experts recognized by the National Landscape Department (NLD). This study applies a qualitative research method, in which researchers have interviewed respondents using specific effective techniques. The MGC is meant for public parks and designed for all uses but has some significant issues. The finding found that intensive promotion, marketing, and advertising can help implement the concept of Malaysian Garden in the future.
\end{abstract}

Keywords: Malaysian Garden; National Identity; Landscape Architecture; Concept Branding

eISSN: 2398-42870 2021. The Authors. Published for AMER ABRA CE-Bs by e-International Publishing House, Ltd., UK. This is an open access article under the CC BYNC-ND license (http://creativecommons.org/licenses/by-nc-nd/4.0/). Peer-review under responsibility of AMER (Association of Malaysian Environment-Behaviour Researchers), ABRA (Association of Behavioural Researchers on Asians/Africans/Arabians) and CE-Bs (Centre for Environment-Behaviour Studies), Faculty of Architecture, Planning \& Surveying, Universiti Teknologi MARA, Malaysia.

DOI: https://doi.org/10.21834/ebpj.v6iSI4.2914

\subsection{Introduction}

If we mention something about a garden or landscape design concept, we must consider the local community's cultural factors and lifestyles. A nation that has a great civilization since thousands of years ago had a comfortable and structured life. The gardens and landscapes are very carefully related to the human environment. It is where someone might live if they found it all just space without any element. If we talk about MGC, we need to discuss Malaysia's culture and society more deeply. Referring to Wheatley (2010), Abu Dulaf, an Arab trader, when he arrives at "Kalah" in 943 AD., he found that it was very high, with a great wall, various gardens, and abundant springs. "Kalah" is referred to as Kedah, a state in northern Peninsular Malaysia today. It is an example where the Malay community has had a garden since ancient times. This study aims to explore the future of the Malaysian Garden concept. The study's objective is to discover the method of branding the MGC by experts recognized by the NLD.

Promoting the Malaysian Garden is a social responsibility carried out by various parties such as the NLD, local authorities, developers, and institutions (Zakaria et al., 2020a). Something to ponder about is, "Does this concept already have a framework?". Other than that, we should consider answering, "Who should be held responsible for the failure to introduce this concept?". If there is still doubt in answering this question, it is difficult to estimate how long it will take the MGC to establish globally. The NLD has once collaborated with a public university to develop a Malaysian garden research lab/site. Unfortunately, the results of the research are not encouraging. Not many researchers are interested in this topic and are not encouraged to continue. So, it dies or stops just like that. The MGC is a brand that has been created but ignored by the responsible party.

eISSN: 2398-4287C 2021. The Authors. Published for AMER ABRA cE-Bs by e-International Publishing House, Ltd., UK. This is an open access article under the CC BYNC-ND license (http://creativecommons.org/licenses/by-nc-nd/4.0/). Peer-review under responsibility of AMER (Association of Malaysian Environment-Behaviour Researchers), ABRA (Association of Behavioural Researchers on Asians/Africans/Arabians) and cE-Bs (Centre for Environment-Behaviour Studies), Faculty of Architecture, Planning \& Surveying, Universiti Teknologi MARA, Malaysia.

DOI: https://doi.org/10.21834/ebpj.v6iSI4.2914 


\subsection{Literature Review}

\subsection{The Malaysian Garden Concept (MGC)}

How does the idea of a garden owned by the Malays since ancient times been lost today? Zakaria et al. (2017) found that today's Malay society has not been concerned about their environment. Their aesthetic value has faded due to the lack of sensitivity to the knowledge inherited by their ancestors. Why are researchers discussing the Malay community park, even though the topic is really about the MGC? The National Landscape Department (2009) notes that MGC influences the traditional Malay Garden and indigenous ethnic elements in Malaysia. Abu Bakar (2012) endorsed the arguments in his book title, 'The Malaysian Garden Towards a National Identity.' He is one of the NLD experts to discuss the MGC's details. Apart from publishing basic guidelines book to the idea of Malaysian Garden, the NLD has also issued a "National Landscape Policy (NLP)," emphasizing the development of high-value landscapes from visual and cultural aspects. Recommended to refer the Strategy 4.2 - Identify and Develop Landscapes of High Value in Visual and Cultural (National Landscape Policy, 2011).

\subsection{The branding knowledge}

A lack of confidence in Malaysian society is the main problem of introducing the MGC to local and foreign communities. The idea is biased to the traditional elements of the ethnic majority only and designed to represent all ethnicities in Malaysia (Zakaria et al., 2015). For information, Malaysia is a multi-ethnic country. We should rebrand the MGC for its goodness in the future. Why use the MGC? Referring to the Branding Theory by Keller (1993), "Branding Knowledge" can be divided into two parts, namely [1] Brand Awareness; and [2] Brand Image. See Fig. 1 below; researchers find that branding plays an essential role in introducing our products with ease. The three keys to branding a product are Strength, Favorability, and Uniqueness of a product.

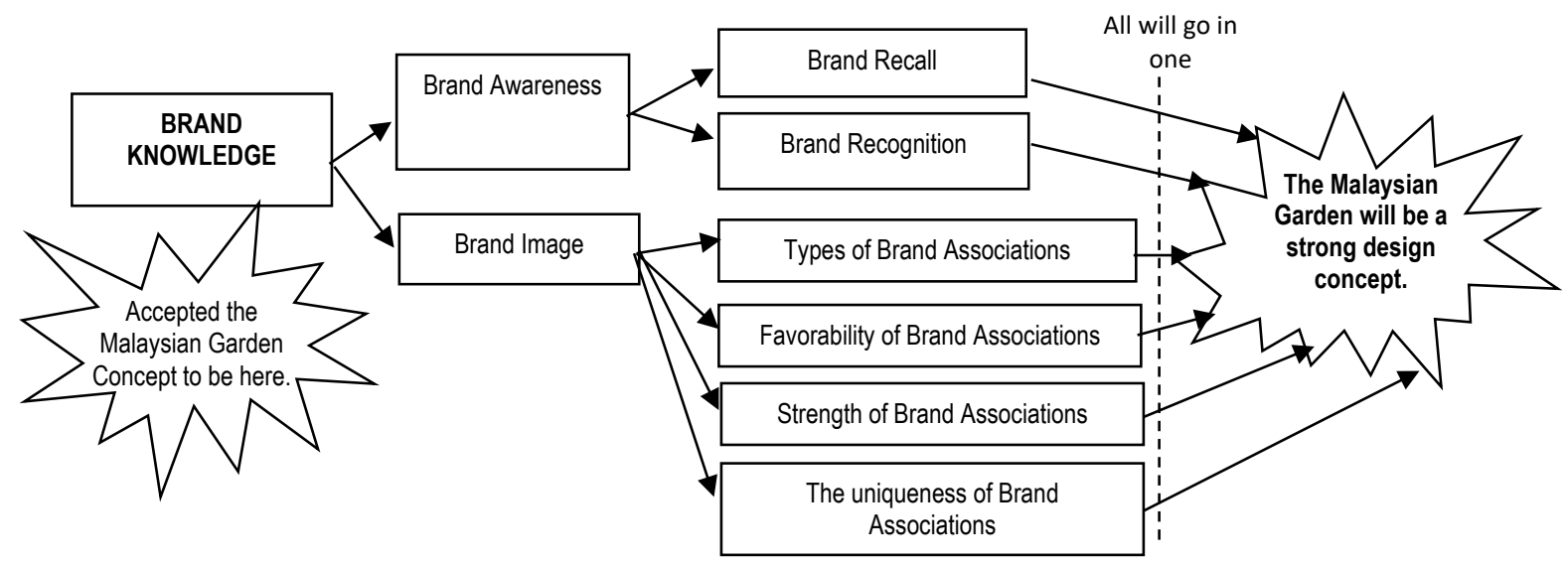

Fig. 1: Dimensions of Brand Knowledge (Source: Inspired by Keller, 1993)

\subsection{Marketing strategy}

Another effort to uphold the concept of Malaysian Garden is to use effective marketing methods. According to AMA (2013), marketing shows as "the activity, set of institutions, and processes for creating, communicating, delivering, and exchanging offerings that have value for customers, clients, partners, and society at large. Marketing is an activity that we make to convince the customer/client to try or feel a new approach. In marketing activities, promotion refers to a type of communication used to inform the public about a product, service, brand, or tool to highlight an issue. Promotion terms are referring to "advertising or publicity" related to "sales promotion" used as an approach in marketing communications (Pickton \& Broderick, 2005).

\subsection{Representation concept}

According to Hall (1997), its means 'mental representation' to the real world. It can be physically produced by a material object that can be seen with our senses or abstractly, a hypothetical example of love, war, and culture. The MGC's basic guidelines are among issues that may be difficult to comply with by the NLD. Refer to Fig. 2 below (author observation and associate with Zakaria's study, 2019a).

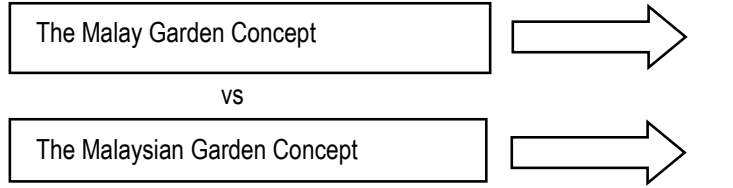

The small compound / private activity / has the element of simplicity in design.

The large garden in size. Everyone can use it. Need detailed statements to be a local identity or iconic

Fig. 2: The difference between the Malay Garden concept and the Malaysian Garden concept. (Author, 2019) 
Researchers agree with the NLD method using a subject matter (traditional Malay element) as the basis for developing the MGC. Theory of Representation by Hall, 1997 states the need for something to be explained of its existence or to illustrate it, to make it easy for people to remember it by themselves, either to place a likeness of it before us in our mind or the senses (Refer to Fig. 3).

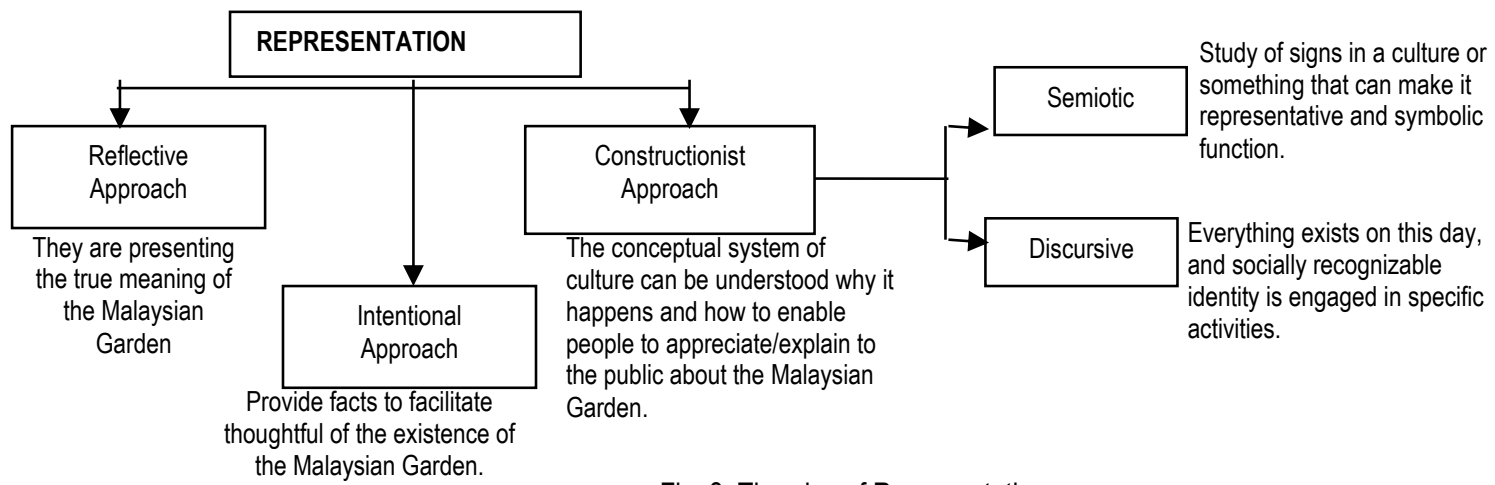

Fig. 3: Theories of Representation

(Source: Adapted from Hall, 1997)

\subsection{Methodology}

This study has adopted a qualitative research method. Geertz (1973) notes that researchers would attempt to "enter" the original conception realm using phenomenological methods. Sampling was carried out using the "Purposeful Sampling" method. This sampling method has been widely used in qualitative research to get accurate and sufficient information (Patton, 2002). Researchers used these methods to facilitate the study as the number of respondents was low, but their distribution was scattered.

This study applies qualitative research methods, where researchers have interviewed respondents, transcribed, and analyzed data using the NVIVO 12 application software. The data were obtained from the interview using the technique "Semi-Structured in-depth." The researchers used this approach since "open-ended" questions focused more on the issue progression. The respondents answered the same queries based on their perception/experience (Meriam \& Tisdell, 2016). There was a total of five (5) respondents interviewed. Each respondent questioned 45-60 minutes/person. Data extraction methods were through face-to-face interviews, digital cameras, recording conversations using voice recorders, and transcribing conversations. Research procedures refer to Figure 4 . All data obtained were analyzed using NVIVO 12 software. Due to time limit factors, only five (5) respondents were interviewed, and fortunately, researchers discovered consistent data (achieve saturation). The reporting in this article is Phase 1 of the investigation. The use of this software has helped researchers in [1] select, and code data based on interpretation, [2] define and cluster codes, [3] spot relationships in the data, and [4] design graphical relationships based on the research findings.

\subsection{Respondents criteria}

The criteria set out in the selection of respondents are as follows:

(1) The MGC experts: There are 21 names in the list referring to the basic guidelines of the MGC (National Landscape Department, 2009).

(2) Having representatives from academia, industry players (consultants and contractors), and policymakers.

(3) Former Director-General of government agencies responsible for ensuring the landscape architecture industry in Malaysia is progressing.

\subsection{Assessments data query}

The assessments made in this study include the following questions:

(1) What is the status of the Malaysian Garden design concept?

(2) How is the public acceptance of the MGC today? What kind of rules and activities can facilitate the introduction of the MGC?

(3) When do stakeholder/industry players/academics play a role in this issue?

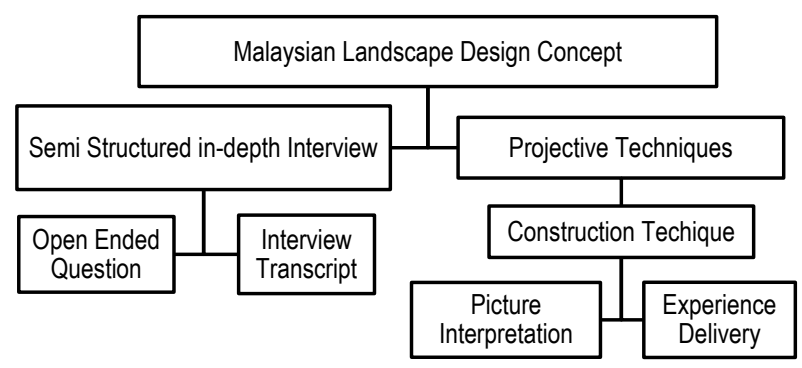

Fig. 4: Research Procedures

(Source: Authors, 2019) 


\subsection{Findings and Discussion}

Interview sessions are organized between January - December 2018. Interviews and transcripts of responses take a long time due to various factors, including the respondents' appointment date and availability. For information, researchers will not provide respondents' information regarding privacy, and the answers given refer to their experience and expertise. The breakdown of the research themes through NVIVO 12 is as follows:

\subsection{The MGC status}

(1) The MGC is supposed to be suitable for public parks, and it is for everyone's use. The shape and size are different if compared to the idea of the Malay Garden. The Malaysian Garden is unlikely to be applied today if we only refer to a race, for example, using only traditional Malay elements in the garden design. It is challenging to satisfy all parties, but efforts need to be taken; otherwise, we will not get the result.

(2) How long does it take us to implement this concept? We do not need the name of Malaysian Garden to attract users to public parks; as long as it is beautiful, clean, maintained, safe, can be used by all societies, and will still use it. However, this is not the issue of the park's name. It is more on applying cultural values, and Malaysian society's identity will show the uniqueness and diversity of attraction, not just locals but tourists from around the world. The weakness of the MGC is the lack of documentation by our ancestors.

(3) Identity is vital in all types of development. If we describe the Holland Garden, we will know its identity is Tulips and Orchids. What is the plant that identifies Malaysia? If we look at the main issue at this point is the design, we lack expertise. We have not been able to produce or groom many experts over the years. The problem of our people today is that they do not value something close to them. Although it is beautiful and comparable to something overseas, we still do not appreciate it, and that is why we more recognize the outside identity than we have.

(4) The most widely used word during the interview was "Malay Garden" and "Malaysian Garden." However, researchers have removed the directory terms as it is a subject matter or study topic. The results show that respondents have used the word "Identity" and "Culture" when answering the question afterward. NLD should highlight the identity and culture of the MGC to users. This screening process uses the NVIVO 12 application in getting the main keyword of this study.

(5) The MGC exists if we refer to the National Landscape Department (2009); however, its promotion agenda was not active for a long time. It shows that the Malaysian Garden brand has been created, but the critical issue is, "Does this made brand positively impact the landscape architecture field?

\subsection{Malaysian society feedback}

(1) The term "Malaysian Garden" is more appropriate than the name "Malay Garden" because other ethnic groups in Malaysia will use it despite deploying many Malay traditional elements in the design. The acceptance of the concept of the Malaysian Garden is currently available. Still, it is not due to the use of the term "Malaysian Garden"; however, they believe the people can accept this concept on the respect factor of the majority race in Malaysia. Other than that, different ethnicities have also adapted to the Malay lifestyle culture.

(2) The park's function and concept are according to user interpretation. As designers, we can make a good garden design, but the perception comes from the user. Indeed, combining the three most substantial ethnic identities in Malaysia is suitable for this concept. However, we need to respect the majority of the population in this country. We need to implement the idea of Malaysian Garden to be an identity and pride for future development.

(3) After programs are executed, we must emphasize the maintenance aspect. Recently the local authority built many public parks in their territory. Unfortunately, its beauty and excellence have not been able to last long due to the lack of funds to maintain and expertise that has cost us millions of Ringgit Malaysia (MYR) when developing something only for immediate use.

(4) The crucial issue to society expressed concerns the "sense of belonging." It is the reason why the multi-racial countries are challenging to come up with a solution. It is the feeling that we are a part of it that is most vital to see value in life and deal with sharply painful emotions. We should be aware that representing the country is not just about the individual or the people but also about symbolizing the whole people in this country. However, some factors need to be emphasized, such as the Malaysian Constitution's social contract (Government of Malaysia- Articles 14-18 \& 153, reprint November 2010).

\subsection{Proposed activities for future development}

(1) We need to give the assignment to disseminate this concept to the Local Authority and government agencies. Researchers from local universities will assist these agencies. It is difficult to make a mistake without government agencies' assistance because government agencies have a budget allocation, but the other party has no provision for this activity. Government agencies need to get started, and industry players will follow the beat of their game.

(2) Most vital if we want to create Malaysia Garden currently is its location selection for its development. For establishing this park, urban areas are a priority. Implementing it in rural areas will make the park less impact, unable to attract many users. Whether the government has provisions for the potential development of a public park, they need concern of some aspect. It is essential to look for a strategic area to have a great view. We can choose it as the first public park to implement the MGC and indirectly be an icon to park development in Malaysia.

(3) The benefits we can get from these ideas can uphold ourselves, convey the societies beyond what we are, our identity, and indirectly bring about economic strength through tourism and commodities related to Malaysian society's cultural heritage. From 
the promotion point of view, we need to be bolder in introducing a tagline or motto that the verse's term can attract the audience or readers, such as 'Malaysia Truly Asia.' Such a sentence can give a brief overview of our country. We need to create a specialized curriculum for understanding the MGC. We need an expert to sustain this concept. What we see today is a problem of implementation, not a design problem.

(4) We have no problem implementing the park concept as we have already proven to win 2 Gold Medals at the Chelsea Flower Show in 2010 and 2011. That means our idea is recognized and able to compete internationally. All we need is diligence from the various authorities. We need to go back to the original goal of creating this concept, "Creating a park with a Malaysian identity and thereby creating a more beautiful environment" (National Landscape Department, 2009).

\subsection{The role of the parties involved in developing landscape architecture in Malaysia}

(1) The government can implement and can start with small projects on government buildings. We can design all green spaces with the concept of Malaysian Garden. An easy way to promote/educate people about the MGC.

(2) Industry players are less aware of what is meant by the MGC. The Local Authority also lacked knowledge about maintaining and identifying native species, and it would also be challenging to develop the concept.

(3) As introduced by the NLD, the concept's strength is from a sustainable cultural perspective and vulnerability. Tropical garden style and blended with local culture is the ultimate goal of garden design.

(4) Implementing this concept is expected to become a 'National Policy,' and then all government agencies will follow the instructions to implement this concept. At that moment, everyone can see the importance of this concept and indirectly enhance the Malaysian landscape industry one level higher. To implement this project is not difficult if it has been one of the 'National Agenda.' We must go back to the necessary thing, and this concept must be accepted by all levels of society, also the government of the day.

(5) Today, we have the initiative to develop the concept of Malaysian Garden, but it does not exist. For example, the NLD financed the Cempaka Lake Garden in Bandar Baru Bangi, Selangor, with a traditional Malay design approach. The Permaisuri Lake Garden, Cheras, developed by Kuala Lumpur City Hall, has some conventional Malay representation when adapting Malay women's designs in an area within the park.

(6) Referring to the respondents' views, all of them stated that the NLD did not carry out their responsibilities and caused all the issues. However, we cannot point the finger at the NLD alone because they are the only executing organization. There are more powerful parties and can make decisions that may not align with what the NLD proposes. The NLD could not get away with what they had started. It will show that they have not worked hard to succeed in resolving the experts appointed by them (it has been agreed to) since 2007 at the Malaysian Garden Seminar.

(7) This research on the concept of Malaysian Garden branding needs to be done in-depth, and it is to be a guide to brands that can be adopted by all members of the community in Malaysia. When brands are known, it is not a problem for us to spread the wings globally. The theory of "Brand Knowledge" needs to be adapted to create a high impact brand. However, it is necessary to address several phases before it is said to be a successful program. Fig. 5 below shows the level of cooperation relationship proposed by the expert of the MGC. It involves stakeholders, government agencies, industry players, academics in universities, and Malaysians in general.

(8)

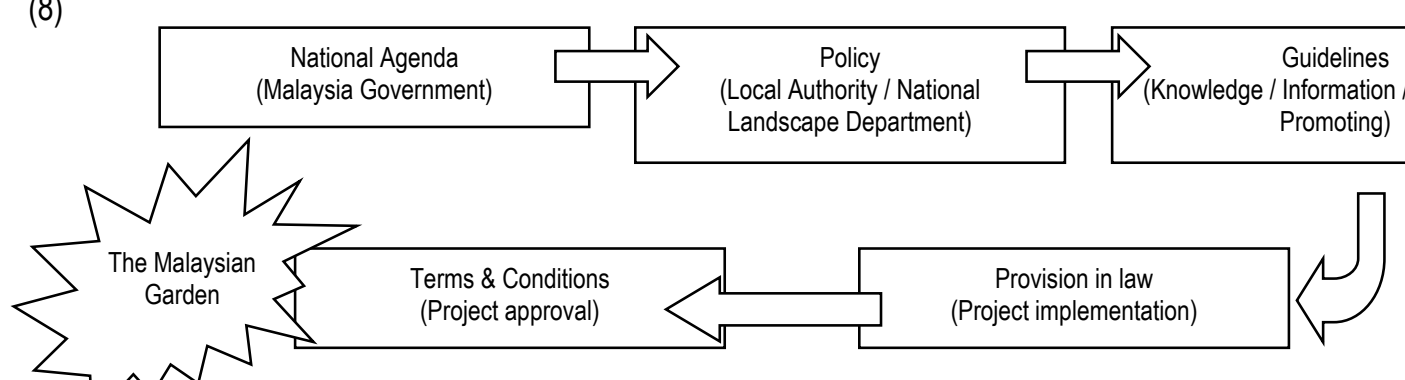

Fig. 5: Stage in implementing the concept of Malaysian Garden (Author, 2019)

\subsection{Branding and Marketing Strategy}

(1) Respondents stated that the MGC is a brand that the NLD is trying to highlight. The study noted such issues, namely:

a. The NLD only issued basic guidelines to guide designers and make confusing design philosophies, intentions, and approaches.

b. It does not make a comprehensive study of branding and marketing strategy. Therefore, it is not strong enough to convince implementers.

c. Adapting to the Theories of Representation, a brand needs to have a Reflective, Intentional, and Constructionist approach. However, it does not show that the NLD is serious in using a 'subject matter' to become a 'brand image' to the MGC.

d. If the preceding is not practical, it will never demonstrate "brands awareness." This concept will not be remembered and failed to attract designers to implement it. 
(2) Among the suggestions made by the respondents to solve the problems identified are:

a. It is involved the agencies such as the Local Authorities, the NLD, and the Institute of Landscape Architects Malaysia (ILAM). They must be essential and consistent in addressing this issue. Every organization needs to improve the promotion methods in all mass media and make it the most trending to see their existence in championing the national agenda.

b. Advertising/promotion/marketing may be more productive with mouth-to-mouth methods. Some companies have long been running the business to implement the concept of Malaysian Garden before the NLD issues their basic guidelines. However, the designs offered are according to their perceptions without an apparent reference.

c. We need to use all media types, such as mass media, electronic media, print media, and social media. If we get 'viral' (campaign: circulated rapidly and widely on the Internet), it will be faster the concept is introduced, but today there is no reference or product that we can 'viral.'

d. The way for today's advertising can use landscape design competition platforms, starting from the school level. However, we must prepare the agreed criteria and guidelines. We can continue this competition to national and professional circles (encouraging all ages, races, and all districts to participate). The NLD cannot exclude any from the media because advertising programs will attract all groups more easily.

\subsection{Conclusion \& Recommendations}

The idea of the Malaysian Garden has existed. However, the guidelines have not been undermined and lack support from the stakeholders (Zakaria et al., 2019b). In conclusion from the findings of this study, branding the concept is the responsibility of (1) the NLD as the organization responsible for initiating this issue, (2) Local Authorities have a budget for implementation and able to tighten requirements for landscape design submission, (3) Institute of Landscape Architects Malaysia, a professional body capable of promoting to its members, (4) government agencies involved in introducing/preserving national heritage such as the Department of National Heritage and Tourism Malaysia, and finally (5) it is the responsibility of the community in this country to introduce this concept by implementing it in their gardens.

As mentioned in the Theory of "Representation," the MGC requires a critical subject matter to represent the entire community. Zakaria et al. (2020b) claim that community acceptance is a must (regardless of the citizens, researchers, designers, local authorities, and decision-makers). Experts have revealed that we can have the concept of a park that can represent our country, but government involvement is the most important because the power they have is unlimited. It will recognize if the government wants to make this one of the 'National Agenda.' Advertising, marketing, and promotion methods help disseminate information to the people if this concept is to be implemented. The MGC will expand the landscape architecture industry and contribute to the tourist attraction in the country, and indirectly have a better economic impact in the future.

For future studies, it is recommended to find common ground or cultural midpoint for each major ethnic group in Malaysia. This culture will be based on the Malaysian Garden's design criteria and not the Malay Garden concept elements directly in the formation of the "New Malaysian Garden." It will require studies on each community's culture, way of life, architecture, heritage, and identity.

\section{Acknowledgement}

We want to express our gratitude to the Research Management Institute (RMI), Universiti Teknologi MARA, for granting full trust to us to do this research. Special thanks to our sponsors, MOHE-Fundamental Research Grant Scheme (FRGS/1/2018/SSI11/UITM/02/8), for providing an adequate provision for this project. Thanks also to the Center for Sustainable Urban Planning \& Real Estate, Faculty of Built Environment, University of Malaya (SUPRE), the Centre for Knowledge and Understanding of Tropical Architecture and Interior (KUTAI), and Taman Alam Melayu Nusantara (T.A.M.A.N) UiTM Perak Branch for the invaluable support during the research period.

\section{References}

Abu Bakar, J. (2012). Taman Malaysia Ke Arah Identiti Nasional (The Malaysian Garden Towards a National Identity), Penerbit UTM Press, Malaysia. American Marketing Association - AMA (2013). What is Marketing? The Definition of Marketing, Retrieved from [https://www.ama.org/the-definition-of-marketing/] Geertz, C. (1973). The Interpretation of Cultures. New York: Basic Books.

Government of Malaysia (reprint November 2010). Federal Constitution- Article 14-18 \& 153, Printed with The Consent of The Yang Di-Pertuan Agong Pursuant to Article 160a of The Federal Constitution, Retrieved from [http://www.agc.gov.my lagcportal/uploads/files/Publications/FC/Federal\%20Consti\%20(BI\%20text).pdf], 27-30 \& 145147 .

Hall, S. (Ed.) (1997). Representation: Cultural Representations and Signifying Practices. Chapter 1: Representation, Meaning and Language, London Thousand Oaks, California: Sage in association with the Open University.

Meriam, S.B. \& Tisdell, E.J. (2016). Qualitative Research: A Guide to Design And Implementation (4th Edition), Jossey-Bass, USA.

National Landscape Department (2009). Taman Malaysia Untuk Diwarisi (The Malaysian Garden to be Inherited), Ministry of Housing and Local Government, Malaysia. 
National Landscape Department (2011). National Landscape Policy: Malaysia Beautiful Garden Nation, Ministry of Housing and Local Government, Malaysia.

Patton, M.Q. (2002). Qualitative Research and Evaluation Methods. 3rd Sage Publications; Thousand Oaks, CA.

Pickton, D. \& Broderick, A. (2005). Integrated Marketing Communications, Harlow, Essex, Pearson.

Wheatley, P. (2010). The Golden Khersonese, University of Malaya Press, Kuala Lumpur.

Zakaria, A.Z., Abd. Rashid, M.S. \& Ahmad, S. (2017). Hardscape and Softscape Elements of a Malay Garden, Pertanika Journal of Social Sciences and Humanities (25 February), 109-118.

Zakaria, A.Z., Dali, M.M. \& Hussein, H. (2019a). Implementing the Malaysian Heritage Garden as the Identity for National Landscape: Case Study in Putrajaya International Journal of Academic Research, in Business and Social Sciences, 9(1), 898-914.

Zakaria, A.Z., Dali, M.M. \& Hussein, H. (2019b). Understanding and Interpreting the Concept of Malaysian Garden Design: Experts Conferring, International Journal of Recent Technology and Engineering, 8(Issue-2S11), 2277-3878.

Zakaria, A.Z., Dali, M.M. \& Hussein, H. (2020a). A Comparative Study of the Malaysian Garden Concept (MGC) Criteria Application on the Public Parks, International Journal of Advanced Science and Technology, 29(7s), 211-217.

Zakaria, A.Z., Dali, M.M. \& Hussein, H. (2020b). "The Malay Garden" is "The Malaysian Garden (MGC)": The Reality and Challenges of Establishing a National Identity, International Journal of Psychosocial Rehabilitation 24(8), 3524-3532.

Zakaria A.Z., Salleh I.H., Harun S.N., Rashid M.S.A. (2015). Preservation Characteristics of Malay Garden: A Catalyst for Sustainable Cultural Landscape in Malaysia In: Hassan O., Abidin S., Legino R., Anwar R., Kamaruzaman M. (eds) International Colloquium of Art and Design Education Research (i-CADER 2014). Springer Singapore, 265-275. 